\title{
THE SOCIALIZATION OF VISUAL MEDIA PROMOTION ON ANCOL YOUTH COMMUNITY IN SUNDA KELAPA
}

\author{
Ariani Wardhani, Novena Ulita, Hady Soedarwanto \\ Universitas Mercu Buana Jakarta, Indonesia
}

\begin{abstract}
The results of a survey that has been released by UNESCO in 2017, Indonesia occupies the 60th position from 61 countries in terms of reading interest. These results are in line with the results of the preliminary survey that has been conducted by a community dedication team within the District of South Meruya. The results of the preliminary survey show that the reading interest in this area has been very low as having been indicated by the number of the books that the people in South Meruya have read. Such low reading interest might bring about negative impact whereas in the digital era information might be accessed easily from numerous media including the social one. As a result, information that have been retrieved might not be filtered and thus the information might be skewed; in turn, misreading on the information might lead to provocation and even chaos. Therefore, a community service in the domain of reading activities within the District of Meruya Selatan is held in order to forge the literacy within the area. With regards to the objective, through the study the researchers would like to design a reading corner with the objective of providing access to the interesting yet useful reading materials for the community. By doing so, it is expected the reading interest and the knowledge of the community in the District of South Meruya might be improved so that a community with high-quality life might be created.
\end{abstract}

Keyword : Web Design, Promotion, Psychotic

\section{INTRODUCTION}

Up to date, the non-profit organizations, especially the ones under the government authority, has strict layout in their information media; as a result, these media has drawn less attention from the viewers. This situation is quite unfortunate because the presence of information media has significant importance in serving as a support tool. If the information media function well, then the interesting information might be understood well. In other words, the layout of information media that does not have sufficient design will be useless. In relation to the statement, it is this case that the UILS (Unit Informasi Layanan Sosial, Unit of Social Service Information) has been experiencing.

The UILS is under the authority of the Social Department in the Province of Jakarta Special Capitol and serves as an information channel with focus on handling ODGJ (Orang Dengan Gangguan Jiwa, People with Mental Disorder) and ODMK (Orang Dengan Gangguan Mental, People with Mental Problem). Then, one of the objectives behind the establishment of UILS, located in Meruya Selatan Number 33 Kembangan West Jakarta, is to change the society perspective by eliminating the negative stigma that has been associated to psychotic. The most important matter behind the objective is that UILS strives to improve the life quality and to protect the life of the psychotic patients through a number of therapies and activities such as culinary training, painting, musical training, sewing, creating puppets and more.

\section{BENEFITS}

Through the number of the activities that has been mentioned above, it is expected that the participants will be able to:

1. Have websites that might deliver information and promote the artworks by the psychotic patients

2. Attain knowledge and skills related to the importance of understanding the web management techniques

3. Attain new knowledge and insight about good information management

On the contrary, the benefit that the team would like to attain through the program implementation is that the team will be able to maintain the relationship and the equality between the science that has been developed in the university and the present condition in the society.

\section{METHOD}

The conduct of the Community Service Program was intended to improve the promotional media that took the form of UILS Meruya Website. Then, the strategic target of the Community Service Program was the non-profit organization named UILS Meruya. Specifically, the strategic target of the program was the needs of 
the UILS caretakers in designing the promotional media because the UILS Meruya had many potentials with great sale value. The design was important to pursue in order that the UILS Meruya might manage the artworks of the psychotic patients with high sale value online.

Then, in conducting the Community Service Program, the following methods were implemented:

1. Explaining the function of good promotional media

2. Introducing the user-friendly application

3. Explaining the icons in the web design based on their functions

4. Explaining how to implement the web application easily and systematically

5. Arranging the materials (product pictures) into the website

6. Providing opportunities for the UILS Meruya to arrange several materials

Furthermore, the conduct of the Community Service Program in the form of website design creation was divided into three stages. The first stage was the preparation stage. In this stage, the Community Service Team from Mercu Buana University visited the UILS Meruya located in Meruya Selatan Number 33 Kembangan West Jakarta. Next, the second stage was the training sessions of media information design. In this stage, the Community Service Team provided explanation about the promotional media that the UILS Meruya might need. Last but not the least, the third stage was the design practice. In this stage, the caretakers of UILS Meruya designed their own web through the free website application that had been explained previously.

\section{ACTIVITY REPORT}

The Faculty of Design and Creative Art and the Unit of Community Service from Mercu Buana University has conducted Community Service Program on February $14^{\text {th }}-15^{\text {th }}, 2019$, in the form of productive activities for the UILS Meruya. The results of the productive activities are in the form of the introduction and the launching of UILS Meruya Website and also the training of web management for displaying information and promoting the artworks by the psychotic patients in the the UILS Meruya.

The website design activities have been prepared prior to the conduct of the Community Service Program. Then, the activities begin with the e-mail registration and identity completion for the UILS Meruya so that the caretakers of UILS Meruya might access Wix (the web platform) easily. Then, the template of the web design has already been available in the web platform; thus, during the conduct of the Community Service Program, both the demonstration and the training process run smoothly due to the facilitation by Wix. The tools in Wix are user-friendly. Not to mention, through Wix the caretakers of UILS Meruya might easily add texts and pictures in the similar manner to the operation of MS Office. As a result, the caretakers of UILS Meruya might easily get familiar to the web platform. The overall process in designing the web might be consulted in the following figures.

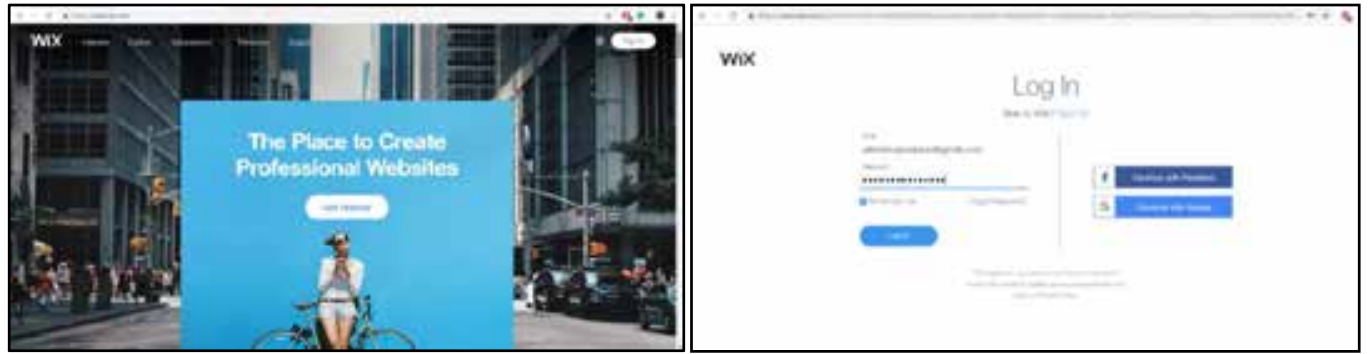

Figure 1. Entrance and Registration Process in Wix

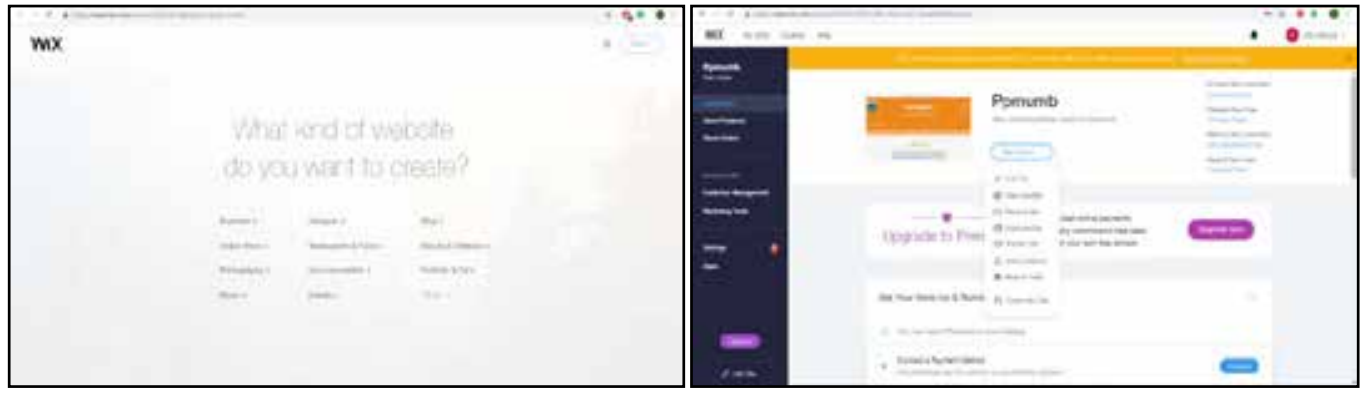

Figure 2. Dashboard Layout of Wix for the Design of UILS Website 


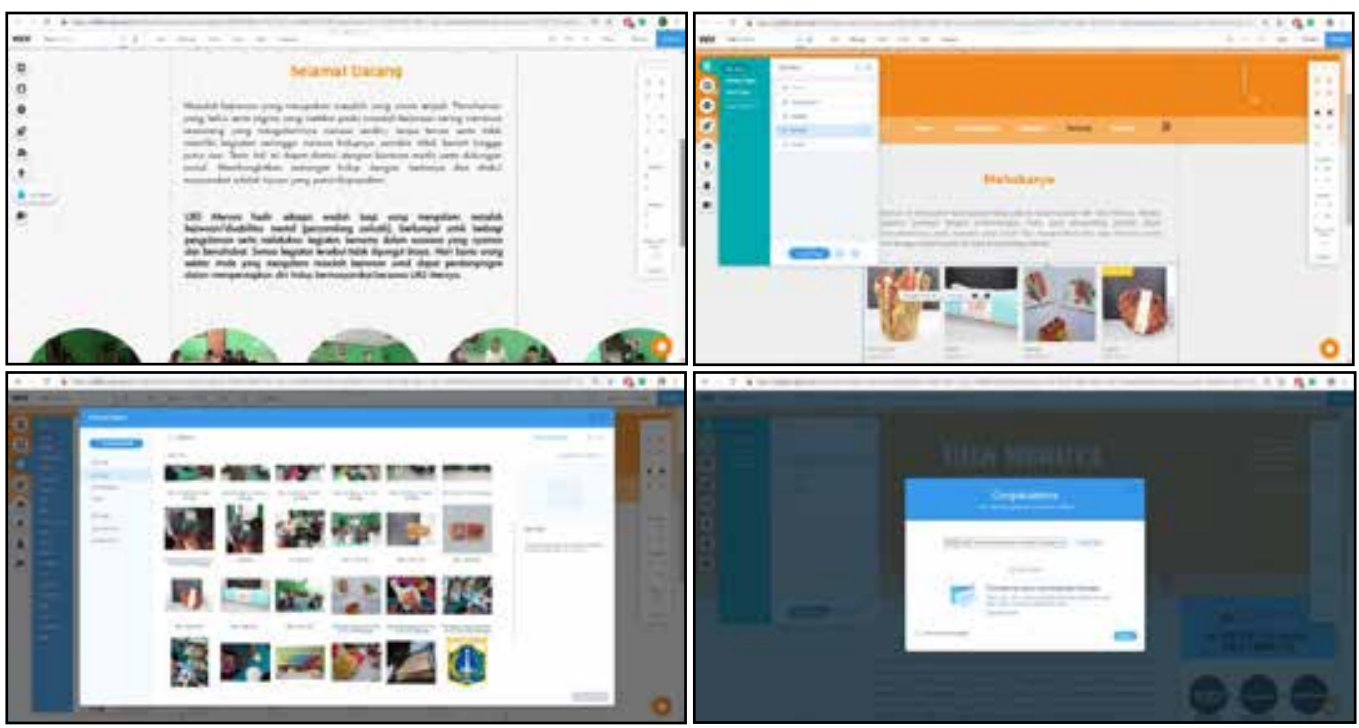

Figure 3. Content Design for the UILS Website

After the design process has been completed, the UILS Website might be accessed through the following link: https://uilsmeruyaselatan.wixsite.com/ppmumb.

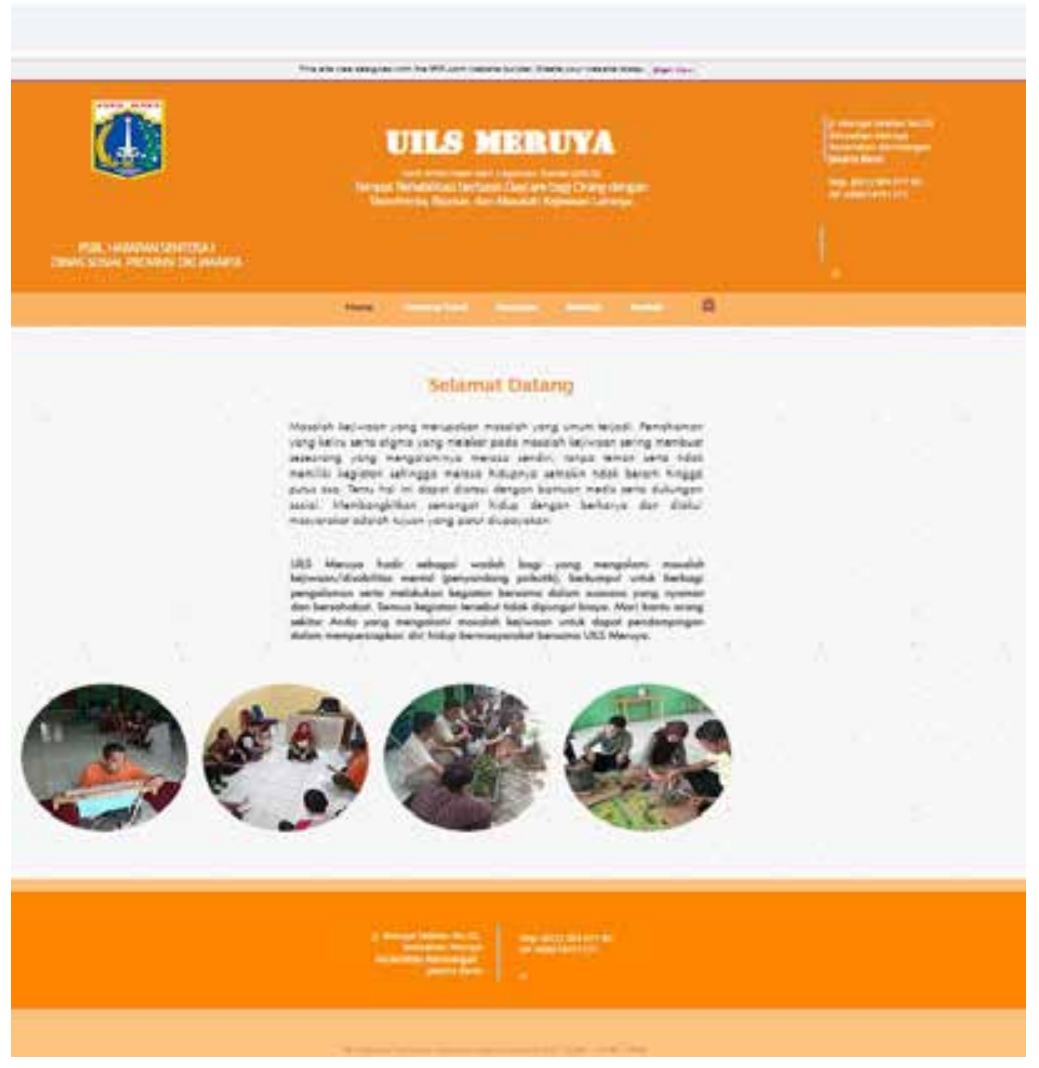




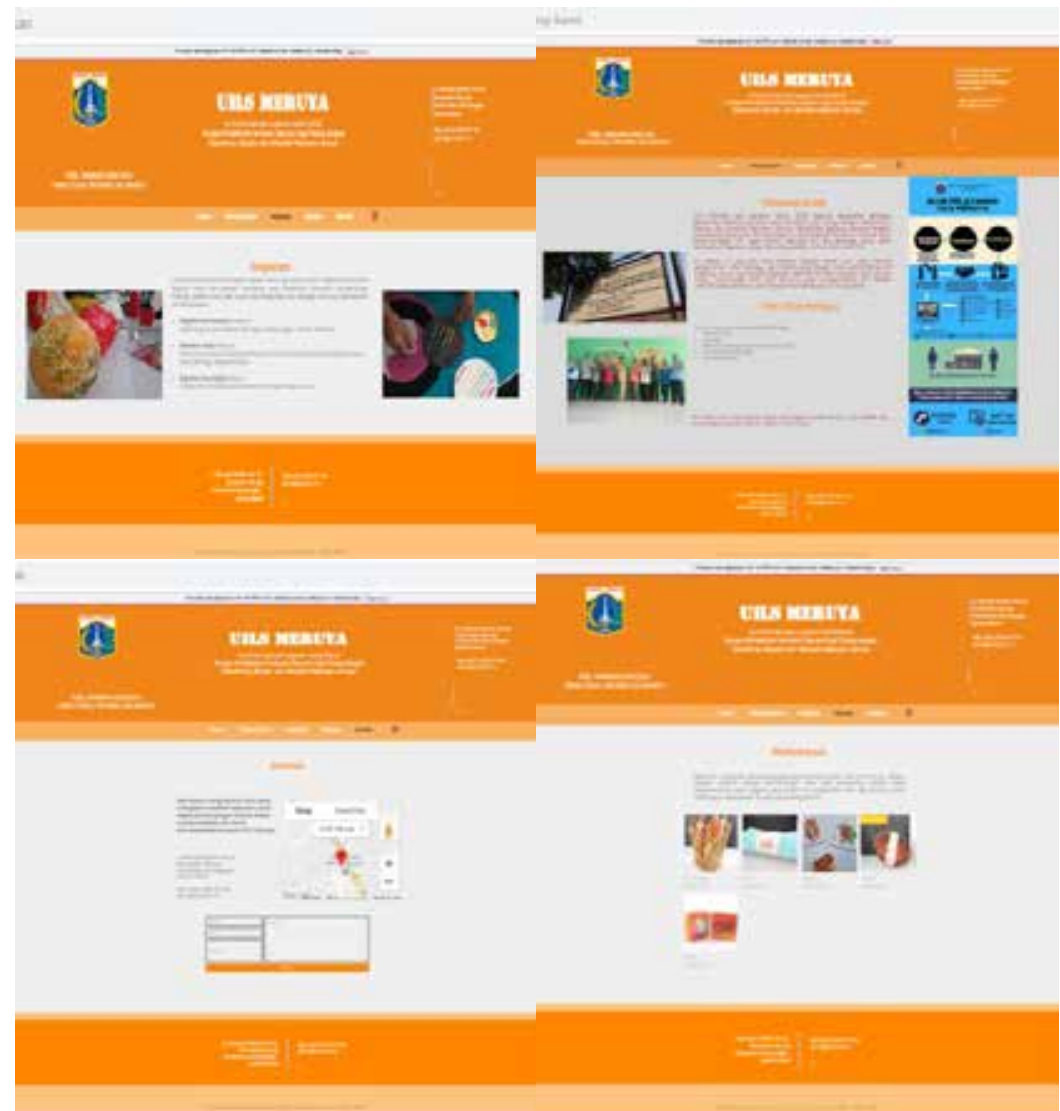

Figure 4. UILS Website

Source: Yasmin, 2019

After the web design has been completed, the next session is training the UILS officers to manage the information and the promotion through the web. The activities in this session might be consulted in the following figures.

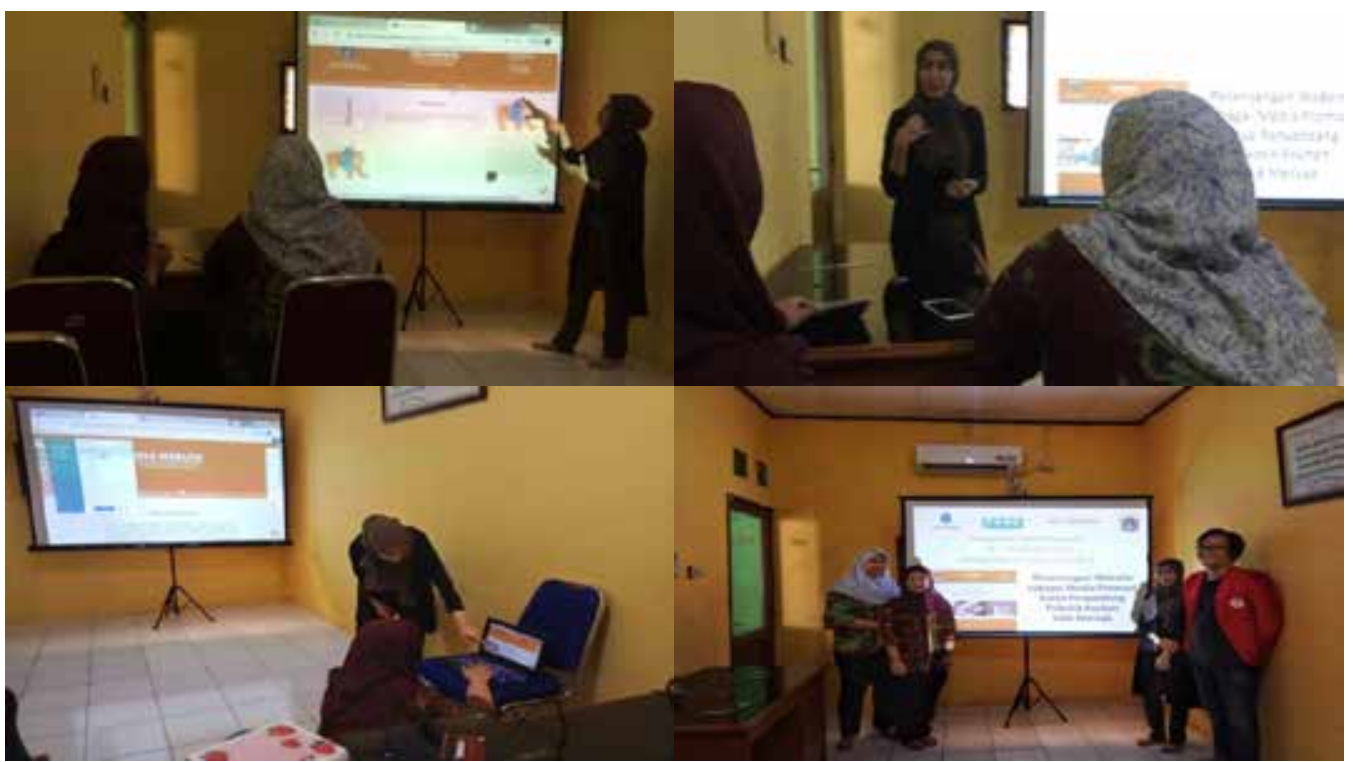

Figure 5. Training Process of UILS Meruya Website Management Source: Yasmin, 2019 


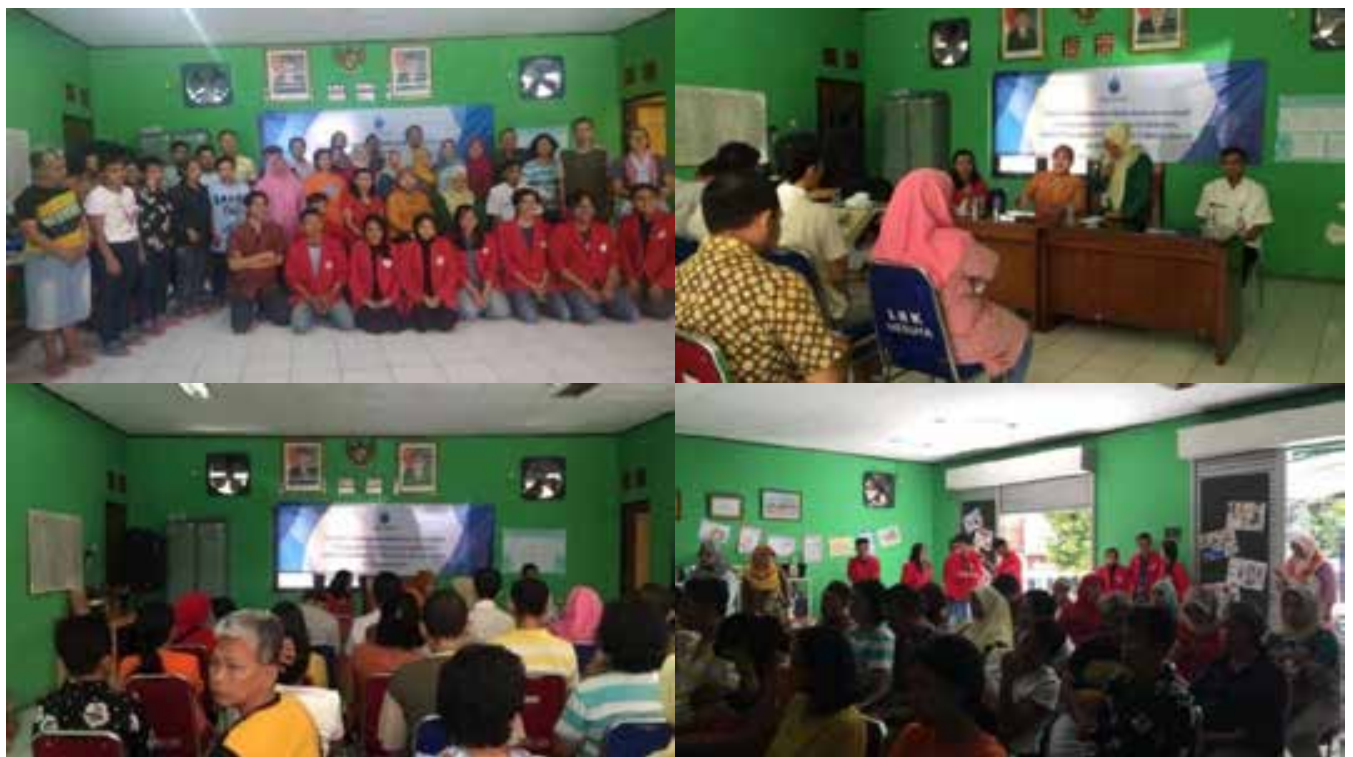

Figure 6. Closing Session and MoU and MoA Signs between the Unit of Community Service from Mercu Buana University and the caretakers of UILS Meruya

Source: Team of Community Service \& Faculty of Design and Creative Art, Mercu Buana University

\section{CONCLUSIONS}

The activities of website management design training program have earned good appreciation from the UILS Meruya. The website that has been designed and developed by the UILS Meruya through the training program does not only serve to access information but also to promote the artworks by the psychotic patients in the UILS Meruya. In relation to the website management, both the Faculty of Design and Creative Art and the Unit of Community Service from the Mercu Buana University has provided their assistance in the form of training the caretakers to pack the artworks of the psychotic patients through simple photography techniques with eye-catching and interesting layout so that the products will draw the interest of the visitors as these products are uploaded onto the website. Through the presence of the website, it is expected that the access for disseminating and promoting the products of the psychotic patients in the UILS Meruya might be facilitated and be expanded.

\section{LIST OF REFERENCES}

Moriarty, Sandra, dkk, Advertising, edisi kedelapan, 2009, Penerbit Kencana, Jakarta.

Hasni, Fatimah Yasmin, Pelatihan Mendesain Media Informasi Bagi Petugas Unit Informasi Layanan Sosial (UILS) Meruya, Jakarta, 2017, PPM Universitas Mercu Buana, Jakarta. Gottfried, Greg, WIX Tutorial for Beginners-full wix tutorial,2018, Youtube:
https://www.youtube.com/watch?v=RAFu 452pME 